\title{
A study on processing conditions of fermented acerola juice
}

\author{
Thanh T. Le*, \& Tuyen C. Kha \\ Faculty of Food Science and Technology, Nong Lam University, Ho Chi Minh City, Vietnam
}

\begin{abstract}
ARTICLE INFO
Research Paper

Received: May 07, 2018

Revised: June 12, 2018

Accepted: August 28, 2018

Keywords

Enzyme pectinex ultra SP-L Fruit juice

Saf-instant yeast

\section{*Corresponding author}

Le Thi Thanh

Email: lethanh@hcmuaf.edu.vn

ABSTRACT

This study investigated some key processing steps of fermented acerola juice, including variety, maturity, enzyme treatment, sugar concentration and fermentation and pasteurization conditions. One or two-factor experiments were randomly designed to determine the most suitable processing variables based on the investigated parameters, including the content of vitamin $\mathrm{C}$, sensory quality and physicochemical properties of the resultant juice.

The results showed that the Brazil variety (Malpiphia emarginata D.C) had highest vitamin $\mathrm{C}$ content $(1567.9 \mathrm{mg} / 100 \mathrm{~g})$, followed by sour variety (Malpiphia glabra L.) $(882.9 \mathrm{mg} / 100 \mathrm{~g})$ and sweet variety (Malpiphia punicifolia L.) (630.4 mg/100 g). However, according to sensory evaluation results, the sour acerola juice after fermentation had the highest overall score, indicating to be the most suitable for processing. The fermented juice of sour acerola variety at $100 \%$ maturity had the highest sensory score and vitamin $\mathrm{C}$ content compared to other levels of maturity. In order to enhance the clarity of acelora juice, the addition of $0.15 \%$ pectinase enzyme (Pectinex ultra SPL, Novozymes) was the most effective compared to 0.05 and $0.1 \%(\mathrm{w} / \mathrm{w})$ enzyme concentrations. The fermentation at $15^{0} \mathrm{C}$ in 48 hours with $22 \%$ sugar concentration and $0.1 \%$ commercial yeast (Saf-instant, France) obtained the highest quality fermented juice. The fermented product was pasteurized at $80^{\circ} \mathrm{C}$ for 10 minutes to stop fermentation process as well as to retain the color and taste of the fermented juice. The good quality of the fermented acerola juice, in terms of physicochemical, sensory and microbiological properties could be maintained for at least 6 months.
\end{abstract}

Cited as: Le, T. T., \& Kha, T. C. (2018). A study on processing conditions of fermented acerola juice. The Journal of Agriculture and Development 17(5), 123-136. 


\title{
Nghiên cứu quy trình chế biến nước sơ ri lên men
}

\author{
Lê Thị Thanh* \& Kha Chấn Tuyền
}

Khoa Công Nghệ Thực Phẩm, Trường Đại Học Nông Lâm TP. Hồ Chí Minh, TP. Hồ Chí Minh

\section{THÔNG TIN BÀI BÁO}

Bài báo khoa học

Ngày nhận: 07/15/2018

Ngày chỉnh sửa: $03 / 03 / 2018$

Ngày chấp nhận: 28/08/2018

\section{Từ khóa}

Enzyme Pectinex ultra SP-L

Nấm men Saf- instant

Nước sơ ri lên men

\section{*Tác giả liên hệ}

Lê Thị Thanh

Email: lethanh@hcmuaf.edu.vn

\section{TÓM TẮT}

Đề tài đã nghiên cứu một số thông số kỹ thuật chính trong quy trình chế biến nước sơ ri lên men bao gồm giống sơ ri, độ chín của giống, bổ sung enzyme pectinex, nồng độ đường, điều kiện lên men và chế độ thanh trùng. Các thí nghiệm được thiết kế theo kiểu hoàn toàn ngẫu nhiên một hoặc hai yếu tố, để xác định các yếu tố xử lý phù hợp nhất dựa trên các thông số đánh giá, bao gồm hàm lượng vitamin $\mathrm{C}$, chất lượng cảm quan và tính chất hóa lý của nước quả.

Nghiên cứu cho thấy giống sơ ri Brazil (Malpiphia emarginata DC) có hàm lượng vitamin $\mathrm{C}$ cao nhất $(1567,9 \mathrm{mg} / 100 \mathrm{~g})$, tiếp theo là giống sơ ri chua (Malpiphia glabra L.) $(882,9 \mathrm{mg} / 100 \mathrm{~g})$ và giống sơ ri ngọt (Malpiphia punicifolia L.) $(630,4 \mathrm{mg} / 100 \mathrm{~g})$. Tuy nhiên, theo kết quả đánh giá cảm quan, sơ ri chua sau lên men có điểm tổng thể cao nhất, phù hợp cho quá trình chế biến. Nước lên men thu được từ giống sơ ri chua này ở độ chín $100 \%$ đạt điểm cảm quan và hàm lượng vitamin $\mathrm{C}$ cao nhất so với các mức độ chín khác. Để hỗ trợ làm trong dịch quả, tỷ lệ bổ sung enzyme pectinase (Pectinex ultra SPL, Novozymes) 0,15\% có hiệu quả hơn so với với tỉ lệ $0,05 \%$ và $0,1 \%$. Quá trình lên men ở nhiệt độ $15^{\circ} \mathrm{C}$ trong 48 giờ với nồng độ đường $22 \%$ và tỉ lệ men (Saf-instant, Pháp) bổ sung $0,1 \%$ cho nước lên men sơ ri có chất lương tốt chất. Sản phẩm sau lên men được thanh trùng ở $80^{\circ} \mathrm{C}$ trong 10 phút ức chế được quá trình lên men cũng như giữ được màu sắc, mùi vị cho sản phẩm nước sơ ri lên men. Sau 6 tháng bảo quản, chất lượng dinh dưỡng, cảm quan và vi sinh vật của sản phẩm thay đồi không đáng kể.

\section{1. Đặt Vấn Đề}

Sản phẩm nước quả lên men có độ cồn thấp là một sản phẩm giá trị dinh dưỡng cao và có lợi cho sức khỏe (Delva \& Schneider, 2013). Hiện nay, sản phẩm này đang là một loại đồ uống giải khát được ưa chuộng trên thị trường thế giới, đặc biệt là các nước Mỹ, Pháp, Anh. Sản phẩm được yêu thích không chỉ vì giá trị dinh dưỡng mà vì đây là loại đồ uống thích hợp với mọi lứa tuổi đặc biệt là phụ nữ và người già. Nước quả lên men có hàm lượng cồn không cao nhưng đủ tạo nên sự kích thích tiêu hóa, giúp bữa ăn trở nên ngon miệng hơn, không gây say như một số sản phẩm đồ uống có cồn khác.

Sơ ri được biết đến như một loại quả có thành phần dinh dưỡng cao rất có lợi cho sức khỏe con người, có hương vị thơm ngon. Hàm lượng vitamin $\mathrm{C}$ trong sơ ri rất dồi dào, chiếm 695 - 4827 $\mathrm{mg} / 100 \mathrm{~g}$ (Delva \& Schneider, 2013), cao hơn ổi gấp 5 - 20 lần và cao hơn xoài khoảng 10 - 15 lần (Lam, 2009). Sơ ri là loại cây ăn quả có trái nhỏ, vỏ mỏng được trồng phổ biến ở khu vực đồng bằng sông Cửu Long, tuy nhiên chúng rất dễ bị dập và hư hỏng, dẫn đến thời gian bảo quản ngắn. Với thổ nhưỡng thuận lợi cùng điều kiện khí hậu nhiệt đới gió mùa cũng như các điều kiện sinh thái khác đã mang lại sản lượng lớn (10000 tấn/năm). Do vậy, nếu tận dụng được nguyên liệu sơ ri để chế biến thành sản phẩm có giá trị, như là nước uống lên men có chất lượng cao về dinh dưỡng và cảm quan, là cần thiết. Nghiên cứu này đã được thực hiện để xác định các thông số chính trong quy trình chế biến nước sơ ri lên men. 


\section{Vật Liệu và Phương Pháp Nghiên Cứu}

\subsection{Nguyên vật liệu}

Sơ ri được mua từ huyện Gò Công - Tiền Giang vào lúc sáng sớm mới thu hoạch, trong thời gian từ tháng $3-12 / 2017$. Nguyên liệu được lựa chọn theo tiêu chí như trái đồng đều về kích cỡ, còn nguyên vẹn, không bị dập nát và sau đó được phân loại theo yêu cầu của từng thí nghiệm.

Chế phẩm Enzyme Pectinex ultra SP-L (chứa polygalacturonase EC 3.2.1.15) nhập khẩu của Novozymes. Nấm men sử dụng là loại nấm men thương mại sấy khô (Saccharomyces cerevisiae), với nhãn hiệu "Saf-instant" xuất xứ từ Pháp.

\subsubsection{Khảo sát sự ảnh hưởng của giống sơ ri đến chất lượng sản phẩm}

Để đánh giá chất lượng nguyên liệu và xác định giống sơ ri thích hợp để làm sản phẩm nước sơ ri lên men, ba giống sơ ri gồm: sơ ri ngọt (Malpiphia punicifolia L.), sơ ri chua (Malpiphia glabra L.) và sơ ri Brazil (Malpiphia emarginata D.C) đã được khảo sát các chỉ tiêu như độ Brix; axít tổng; pH; vitamin $\mathrm{C}$ và đánh giá cảm quan để chọn ra giống được ưa thích nhất.

\subsubsection{Khảo sát ảnh hưởng của độ chín nguyên liệu sơ ri đến chất lượng sản phẩm}

Ba mức độ chín của sơ ri được nghiên cứu bao gồm: $85 \%$ (độ chín trưởng thành khi thu hoạch, màu xanh chuyển hồng nhạt sáng), $90 \%$ (bắt đầu chuyển từ xanh hồng qua đỏ hồng sáng) và $100 \%$ (màu vỏ quả chuyển đỏ sậm hoàn toàn) đã được khảo sát nhằm xác định độ chín thích hợp của nguyên liệu phù hợp với quy trình chế biến nước sơ ri lên men. Nước sơ ri trước và sau lên men được đánh giá về độ Brix, axít tổng, hàm lượng vitamin $\mathrm{C}$, đường tổng và đường khử; và cảm quan nước sơ ri sau khi lên men.

\subsubsection{Khảo sát ảnh hưởng của tỷ lệ enzyme bổ sung hỗ trợ làm trong sản phẩm}

Để xác định tỷ lệ enzyme thích hợp hỗ trợ làm trong dịch quả, thí nghiệm 1 yếu tố gồm 4 nồng độ enzyme: $0 \%$ (đối chứng); $0,05 \% ; 0,1 \%$ và $0,15 \%$ đã được thực hiện với 3 lần lặp lại và tiến hành đánh giá tỷ lệ thu hồi dịch quả, độ Brix, axít tổng, vitamin $\mathrm{C}$, đường tổng, đường khử và độ trong nước sơ ri sau lên men bằng phương pháp cảm quan.
2.1.4. Khảo sát ảnh hưởng nồng độ đường của dịch lên men đến chất lượng sản phẩm

Để tìm ra được nồng độ đường (đường saccharose tinh luyện) thích hợp cho dịch lên men, thí nghiệm 1 yếu tố gồm 4 nồng độ đường bổ sung vào dịch lên men: $0 \%$ (đối chứng), $20 \%, 22 \%, 24 \%$ đã được thực hiện với 3 lần lặp lại và tiến hành đánh giá độ Brix, axít tổng, vitamin $\mathrm{C}$, đường tổng, đường khử, độ cồn và đánh giá cảm quan vị sản phẩm.

\subsubsection{Khảo sát ảnh hưởng của tỷ lệ men bổ sung} đến chất lượng sản phẩm

Để xác định tỉ lệ men bổ sung thích hợp cho lên men, đạt độ cồn mong muốn cho sản phẩm $(<5 \%)$ đồng thời đạt điểm đánh giá cảm quan cao, thí nghiệm 1 yếu tố gồm 4 tỷ lệ men bổ sung: $0 \%$ (đối chứng); $0,05 \% ; 0,1 \%$ và $0,15 \%$ đã được thực hiện với 3 lần lặp lại và tiến hành đánh giá các chỉ tiêu độ Brix, axít tổng, vitamin $\mathrm{C}$, đường tổng, đường khử, độ cồn và cảm quan sản phẩm.

\subsubsection{Khảo sát sự ảnh hưởng của nhiệt độ và thời gian lên men đến chất lượng sản phẩm}

Để xác định được nhiệt độ và thời gian thích hợp cho quá trình lên men, thí nghiệm 2 yếu tố hoàn toàn ngẫu nhiên đã được thực hiện với yếu tố 1 là thời gian (1,2 và 3 ngày) và yếu tố 2 là nhiệt độ $\left(15\right.$ và $\left.30^{\circ} \mathrm{C}\right)$. Thí nghiệm được lặp lại 3 lần và tiến hành đánh giá độ Brix, axít tổng, $\mathrm{pH}$, vitamin $\mathrm{C}$ và cảm quan sản phẩm.

\subsubsection{Khảo sát chế độ thanh trùng ảnh hưởng đến chất lượng sản phẩm}

Nhằm xác định được nhiệt độ và thời gian thích hợp để ức chế quá trình lên men, đảm bảo chỉ tiêu vi sinh thực phẩm, thí nghiệm 2 yếu tố hoàn toàn ngẫu nhiên đã được thực hiện với yếu tố 1 là nhiệt độ thanh trùng $\left(80\right.$ và $\left.85^{\circ} \mathrm{C}\right)$ và yếu tố 2 là thời gian $(5,10,15$ phút). Thí nghiệm được lặp lại 3 lần và tiến hành đánh giá độ Brix, axít tổng, $\mathrm{pH}$, vitamin $\mathrm{C}$ và cảm quan sản phẩm.

\section{2. Đánh giá chất lượng sản phẩm sau 6 tháng bảo quản}

Sản phẩm nước sơ ri lên men sau 6 tháng bảo quản được đánh giá sự thay đổi của một số chi tiêu hóa học như: độ Brix, axít tổng, hàm lượng vitamin $\mathrm{C}$, hàm lượng đường tổng, đường khử, độ 
cồn, và chỉ tiêu vi sinh theo QCVN 6-3:2010/BYT (QCVN, 2010).

\subsection{Phương pháp phân tích các chỉ tiêu}

Độ Brix được đo bằng khúc xạ kế Atago (Nhật) với thang đo $0-33^{0} \mathrm{Bx}$ và 01 số lẻ. Axít tổng được xác định bằng cách chuẩn độ $\mathrm{NaOH} 0,1 \mathrm{~N}$ (Tran \& ctv., 2004). Vitamin C được xác định bằng phương pháp chuẩn độ 2,6-Diclorophenol indophenol (Nguyen, 2004). Đường tổng, đường khử được xác định bằng phương pháp Ferry cyanure (Nguyen, 2004). Độ cồn được đo bằng phương pháp chưng cất theo TCVN 8008:2009. Màu sắc đo bằng máy đo mày CR-400 Minoltal (Nhật) theo hệ $\mathrm{L}^{*}, \mathrm{a}^{*}, \mathrm{~b}^{*}$ bằng cách đo 3 vị trí khác nhau trên trái, đo mỗi mẫu 10 trái và lấy trung bình kết quả đo được.

Đánh giá cảm quan là một trong những chỉ tiêu quan trọng trong nghiên cứu này, nhìn chung người tiêu dùng có khuynh hướng lựa chọn sản phẩm có chất lượng cảm quan tốt (màu sắc, mùi, vị và trạng thái). Theo Lawless \& Heymann (2010), tuỳ thuộc vào mục tiêu của từng thí nghiệm, các phương pháp thích hợp và cảm quan viên đã được sàn lọc và huấn luyện. Cụ thể, phép thử so hàng được lựa chọn khi xác định sự khác nhau giữa các mẫu (các loại giống sơ ri) khi không biết chính xác bản chất của sự khác biệt. Phép thử so hàng thị hiếu (thang điểm 9) được sử dụng để đánh giá cảm quan trong nghiên cứu khi sự khác biệt về các chỉ tiêu cảm quan giữa các mẫu là rất ít. Các cảm quan viên đã được mời nếm thử sản phẩm và đánh giá mức độ ưa thích bằng thang điểm đã được định nghĩa trước thông qua các thuật ngữ mô tả cấp độ hài lòng, ưa thích. Ngoài ra, theo Ha (2000), mỗi mẫu được mã hóa ngẫu nhiên bằng 3 chữ số ngẫu nhiên và các mẫu được đánh giá với 3 lần lặp lại. Hội đồng cảm quan gồm 15 - 30 cảm quan viên đã được chọn lọc và huấn luyện về cách đánh giá cảm quan, thuật ngữ sử dụng, bản chất của sản phẩm và phương pháp đánh giá. Các cảm quan viên (có tuổi từ 20 đến 35) được chọn lựa tham gia đánh giá phải là những người đã từng sử dụng qua sản phẩm nước uống lên men và hiểu được các đặc tính của sản phẩm (Stone \& Sidel, 2004). Trong quá trình huấn luyện, các cảm quan viên đã mô tả được các thuật ngữ như màu sắc, mùi, vị, mùi vị và trạng thái của sản phẩm. Tổng hợp các kết quả và thống nhất các thuật ngữ sử dụng trong quá trình đánh giá bởi hội đồng đánh giá cảm quan (Rocha \& Bolini, 2015). Cụ thể, vị hài hoà được các cảm quan viên đánh giá khi nếm sản phẩm trong một khoảng thời gian nhất định (1 phút) và cảm nhận khi có vị tự nhiên của sơ ri. Đối với đánh giá về mùi vị, ngoài việc nếm sản phẩm, cảm quan viên còn phải nuốt và sau đó cảm nhận về mùi vị.

\subsection{Xử lý số liệu}

Số liệu thu thập được xử lý thống kê bằng phần mềm JMP 10.0 và Microsoft Excel 2013.

\section{Kết Quả và Thảo Luận}

\section{1. Ảnh hưởng của giống sơ ri đến chất lượng sản phẩm}

Việc lựa chọn giống nguyên liệu thích hợp cho chế biến có vai trò quan trọng quyết định đến chất lượng của sản phẩm. Bảng 1 trình bày ảnh hưởng của 3 loại giống sơ ri đến chất lượng hoá học và cảm quan của sản phẩm nước sơ ri lên men.

Kết quả ở Bảng 1 cho thấy, trước khi lên men, hàm lượng axít tổng và vitamin $\mathrm{C}$ của giống sơ ri ngọt thấp hơn 2 giống sơ ri chua và Brazil; kêt quả này tương ứng với kết quả công bố bởi Bộ Nông Nghiệp Hoa Kỳ về độ Brix $(7,69 \%)$, hàm lượng vitamin C $(1677,6$ g). Sau khi lên men, độ Brix, axít, $\mathrm{pH}$ và vitamin $\mathrm{C}$ và cảm quan giữa các mẫu có sự khác biệt ý nghĩa về mặt thống kê ở độ tin cậy $95 \%$. Điều này chứng tỏ 3 giống sơ ri khác nhau về tính chất, đặc điểm ảnh hưởng đến chất lượng sản phẩm. Tổng hợp các kết quả bình luận của các cảm quan viên, mẫu nước lên men chế biến từ giống sơ ri chua đã được đánh giá là mẫu ngon hơn (0,59 điểm) vị chua ngọt hài hòa, mùi thơm. Mẫu sơ ri ngọt theo đánh giá có vị ngọt, thiếu độ chua, màu vàng nhạt hơn, mùi không thơm so với 2 mẫu còn lại. Mẫu sơ ri Brazil được đánh giá tuy mùi thơm, màu đẹp nhưng có vị chua gắt, khó uống (Hình 1).

Từ các kết quả phân tích thành phần hóa học của nguyên liệu và của sản phẩm lên men cho thấy giống sơ ri chua có các thành phần dinh dưỡng cao hơn sơ ri ngọt và thấp hơn sơ ri Brazil. Tuy nhiên về mặt cảm quan thì giống sơ ri chua được đánh giá cao nhất bởi hội đồng đánh giá cảm quan, đồng thời giống sơ ri chua là giống được trồng nhiều ở Việt Nam và có giá thành thấp. Do đó, giống sơ ri chua đã được chọn làm nguyên liệu chính để nghiên cứu chế biến nước sơ 


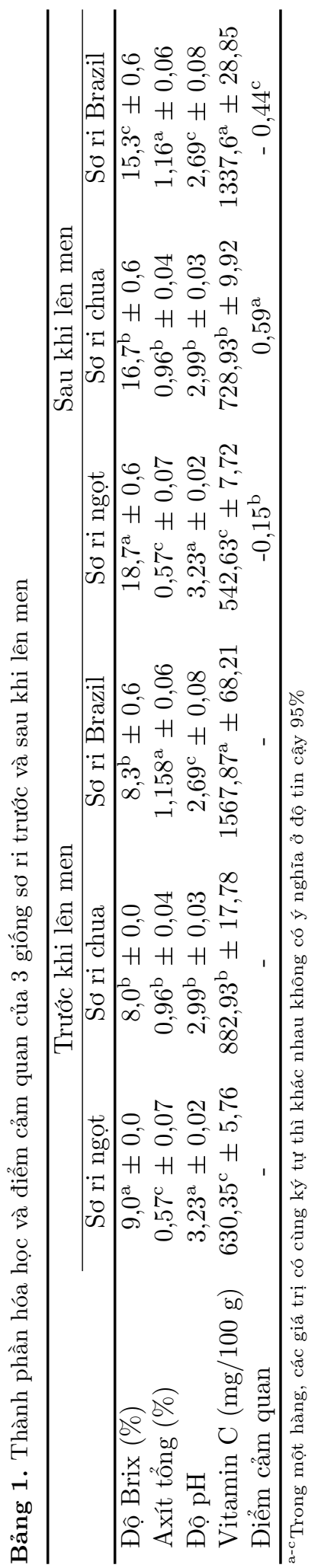

ri lên men.

\section{2. Ảnh hưởng của độ chín nguyên liệu sơ ri đến chất lượng sản phẩm}

Trong công nghiệp chế biến thực phẩm, việc xác định độ chín nguyên liệu thích cho sản xuất là cần thiết. Kết quả đánh giá độ chín nguyên liệu và sản phẩm chế biến được trình bày lần lượt ở Bảng 2 và Hình 2 .

Kết quả ở Bảng 2 cho thấy các chỉ tiêu hóa học giữa các mẫu không có sự khác biệt ý nghĩa về mặt thống kê với $P>0,05$. Hàm lượng vitamin C ở 3 độ chín có sự khác biệt ý nghĩa về mặt thống kê với $P<0,05$. Theo Vendramini \& Trugo (2000), trái sơ ri có hàm lượng vitamin $\mathrm{C}$ giảm dần khi độ chín của trái tăng lên. Nguyên nhân là do tế bào thịt quả phân chia trong giai đoạn chín, các phản ứng trao đổi xảy ra ở cường độ cao và đòi hỏi sự có mặt của những hợp chất chống oxy hóa, trong đó vitamin $\mathrm{C}$ đóng vai trò quan trọng (Horemans \& ctv., 2000; Johnson, 2003). Bên cạnh đó hàm lượng đường tăng lên và độ axít sẽ có xu hướng giảm do có sự thay đổi phức tạp về mặt hóa sinh trong quá trình trưởng thành của trái.

Theo kết quả ở Bảng 2 và Hình 2, có sự khác biệt về mặt thống kê giữa trái sơ ri ở các độ chín khác nhau khi đánh giá bằng phương pháp cảm quan và đo lường bằng thiết bị. Giá trị $\mathrm{L}^{*}$ đặc trưng cho cường độ sáng tối, giá trị a* đặc trưng cho sắc độ đỏ và xanh lá cây, giá trị b* đặc trưng cho sắc độ màu xanh dương đến vàng. Từ 3 giá trị này có thể tính toán được màu sắc khác nhau giữa các mẫu. Ngoài ra, trong các nghiên cứu tiếp theo, cần tính toán sự tương quan về màu sắc giữa đánh giá cảm quan và đo lường bằng thiết bị.

Kết quả ở Bảng 3 cho thấy độ Brix, axít và vitamin $\mathrm{C}$ sau khi lên men theo độ chín của sơ ri không có sự khác biệt với độ tin cậy $95 \%$. Về tỷ lệ thu hồi thì độ chín 90\% đạt tỷ lệ thu hồi cao hơn hai độ chín còn lại. Đối với tỷ lệ hao hụt vitamin C sau 2 ngày lên men từ 16,59\% đến 20,71\%. Đồng thời qua kết quả cảm quan, các chỉ tiêu màu sắc, mùi, vị có sự khác biệt rất ý nghĩa với độ tin cậy $95 \%$. Với độ chín đạt 100\% thì được đánh giá cao và chấp nhận bởi các cảm quan viên nhiều hơn về cả 3 chỉ tiêu màu sắc, mùi, vị: màu vàng trong, có hương thơm đặc trưng của quả sơ ri chín và sản phẩm lên men, vị chua ngọt hài hòa (có tỉ số Brix/axít nằm trong giới hạn yêu cầu theo TCN612:2005 đối với nước dứa cô đặc). 


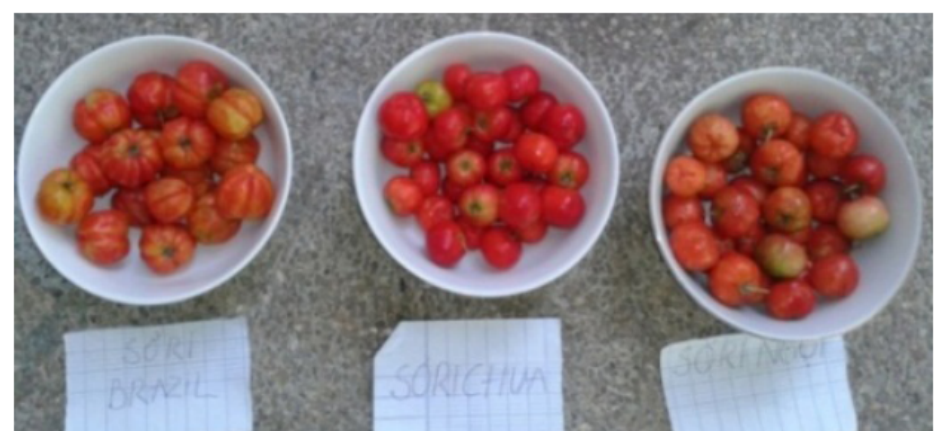

(a) (b) (c)

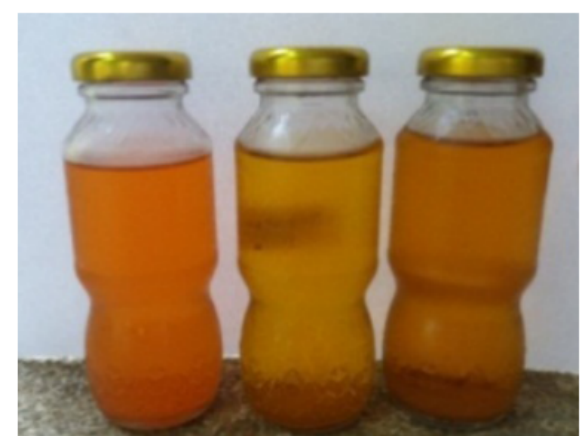

(a) (b)

Hình 1. Ba giống sơ ri và sản phẩm của ba giống sơ ri sau lên men.

(a): Sơ ri Brazil và sản phẩm sau lên men; (b): Sơ ri chua và sản phẩm sau lên men; (c): Sơ ri ngọt và sản phẩm sau lê men.

Từ kết quả chỉ tiêu hóa học và cảm quan, sơ ri chín $100 \%$ đã được chọn để nghiên cứu nước sơ ri lên men.

\section{3. Ảnh hưởng của tỷ lệ enzyme bổ sung hỗ trợ làm trong sản phẩm}

Nhìn chung, độ trong của sản phẩm nước giải khát nói chung và sản phẩm nước sơ ri lên men là một trong những chỉ tiêu chất lượng quan trọng. Có nhiều phương pháp xử lý làm trong dịch quả, tuy nhiên việc sử dung enzyme như enzyme pectinase là một trong những phương pháp xử lý hiệu quả hơn cả, về chất lượng và chi phí (Sharma \& ctv., 2017). Ngoài ra, việc ứng dụng enzyme làm tăng tỉ lệ thu hồi dịch quả cũng được ứng dụng rộng rãi. Trong nghiên cứu này, ảnh hưởng của xử lý enzyme đến tỉ lệ thu hồi và sự thay đổi thành phần hoá lý của nước sơ ri trước khi lên men (Bảng 4) và sau khi lên men (Bảng 5 ) đã được nghiên cứu nhằm xác định tỉ lệ enzyme bổ sung thích hợp.

Bảng 4 cho thấy các chỉ tiêu hóa học không có sự khác biệt ý nghĩa về mặt thống kê $(P>0,05)$. Điều này cho thấy các chỉ tiêu hoá học bị ảnh hưởng không đáng kể bởi xử lý enzyme. Khi có xử lý enzyme, tỷ lệ thu hồi dịch quả cao hơn rất nhiều $(74,57 \%$ đến $82,1 \%)$ so với mẫu không xử lý $(9,07 \%)$. Mặt khác, khi tăng nồng độ enzyme bổ sung từ $0,05 \%$ đến $0,15 \%$ thì quá trình lọc rút ngắn thời gian và thực hiện dễ dàng hơn, trong khi đó không làm thay đổi chất lượng hoá học của dịch quả.

Qua kết quả Bảng 5 cho thấy các chỉ tiêu hóa học của các nghiệm thức không có sự khác biệt về mặt thống kê (với $P>0,05$ ). Về điểm cảm quan độ trong giữa các mẫu có sự khác biệt có ý nghĩa (với $P<0,05$ ). Mẫu đối chứng không được chấp nhận do sản phẩm đục, có nhiều cặn bởi các cảm quan viên. Các mẫu còn lại được đánh giá cao hơn về độ trong. Bên cạnh đó, chúng tôi nhận thấy sắc đỏ của dịch quả tăng dần khi tăng lượng enzyme bổ sung từ $0,05 \%$ dến $0,15 \%$. Theo báo cáo của Sharma \& ctv. (2017), việc ứng dụng enzyme giúp các tế bào thịt qủa được phá vỡ nhanh chống, giúp cho tỉ lệ thu hồi tăng đáng kể, đồng thời các sắc tố cũng được giải phóng dễ dàng hơn. Tuy nhiên, cần có những nghiên cứu tiếp về tối ưu hoá điều kiện xử lý enzyme nhằm gia tăng tỉ lệ thu hồi.

Như vậy, nồng độ $0,15 \%$ cho tỷ lệ thu hồi cao nhất, dịch trong và màu đẹp, tốc độ lọc nhanh, hàm lượng vitamin $\mathrm{C}$ mất tương đối thấp. Do đó, tỷ lệ enzyme xử lý là $0,15 \%$ đã được chọn để thực hiện các thí nghiệm tiếp theo.

\section{4. Ảnh hưởng nồng độ đường của dịch lên men đến chất lượng sản phẩm}

Nhìn chung, chất lượng của sản phẩm bị ảnh hưởng đáng kể bởi các điều kiện lên men. Trong nghiên cứu này, các điều kiện lên men như nồng độ đường (Bảng 6), tỉ lệ nấm men (Bảng 7), nhiệt độ và thời gian lên men (Bảng 8 ) đã được xác định sao cho chất lượng hoá lý và cảm quan là tốt nhất.

Qua kết quả Bảng 6 cho thấy độ Brix, đường tổng, đường khử và độ cồn có sự khác biệt rât ý nghĩa $(P<0,05)$, điều này chứng tỏ hàm lượng 
Bảng 2. Kết quả phân tích thành phần hóa lý nguyên liệu sơ ri theo 3 độ chín

\begin{tabular}{lccc}
\hline \multirow{2}{*}{ Chỉ tiêu } & \multicolumn{3}{c}{ Độ chín } \\
\cline { 2 - 4 } & $85 \%$ & $90 \%$ & $100 \%$ \\
\hline Độ Brix (\%) & $8,7^{\mathrm{a}} \pm 1,0$ & $9,1^{\mathrm{a}} \pm 1,0$ & $9,6^{\mathrm{a}} \pm 1,3$ \\
Axít tổng (\%) & $0,88^{\mathrm{a}} \pm 0,26$ & $0,81^{\mathrm{a}} \pm 0,23$ & $0,78^{\mathrm{a}} \pm 0,12$ \\
Vitamin C (mg/100g) & $1178,53^{\mathrm{a}} \pm 89,40$ & $1024,50^{\mathrm{b}} \pm 33,50$ & $899,20^{\mathrm{b}} \pm 32,69$ \\
Đường khử (\%) & $7,17^{\mathrm{a}} \pm 1,22$ & $7,31^{\mathrm{a}} \pm 0,99$ & $7,68^{\mathrm{a}} \pm 1,11$ \\
Đường tồng (\%) & $6,84^{\mathrm{a}} \pm 0,84$ & $7,29^{\mathrm{a}} \pm 0,95$ & $7,48^{\mathrm{a}} \pm 1,13$ \\
Màu sắc L* & $75,51^{\mathrm{a}} \pm 4,08$ & $68,75^{\mathrm{b}} \pm 3,37$ & $55,38^{\mathrm{c}} \pm 2,38$ \\
\multicolumn{1}{c}{$\mathrm{a}^{*}$} & $-1,66^{\mathrm{c}} \pm 4,27$ & $18,10^{\mathrm{b}} \pm 2,77$ & $34,15^{\mathrm{a}} \pm 1,91$ \\
$\mathrm{~b}^{*}$ & $39,09^{\mathrm{a}} \pm 1,41$ & $35,25^{\mathrm{a}} \pm 0,69$ & $27,39^{\mathrm{b}} \pm 3,41$ \\
\hline
\end{tabular}

a-c Trong một hàng, các giá trị có cùng ký tự thì khác nhau không có ý nghĩa ở độ tin cậy $95 \%$.

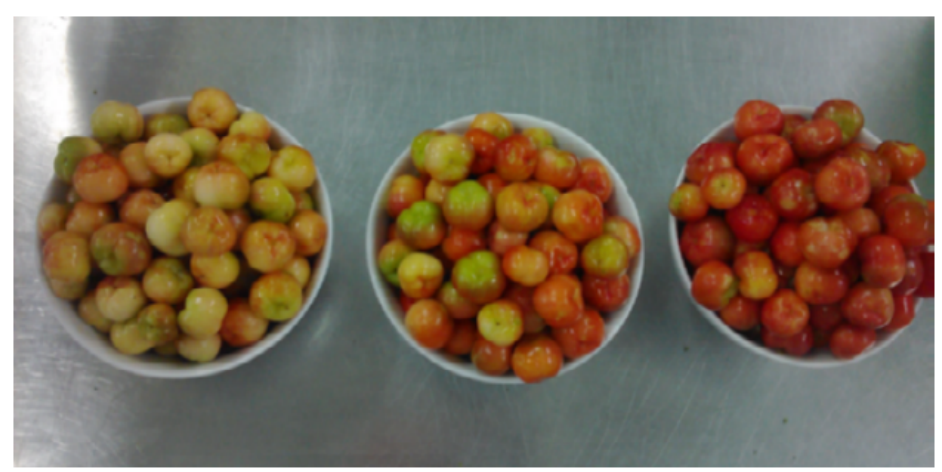

$(85 \%)$
$(90 \%)$
$(100 \%)$

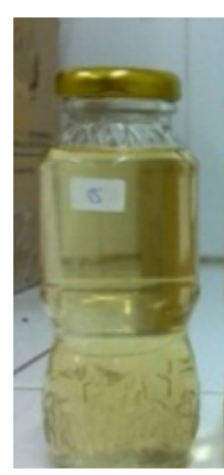

$(85 \%)$

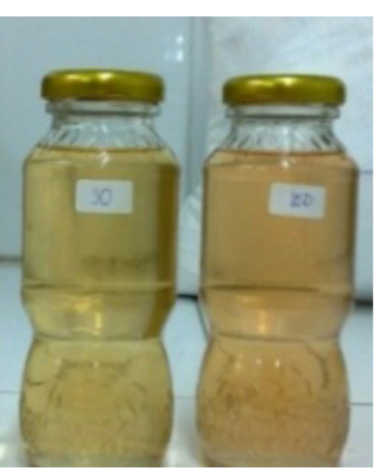

$(90 \%)$

$(100 \%)$

Hình 2. Nguyên liệu sơ ri và sản phẩm nước lên men từ sơ ri ở 3 mức độ chín.

Bảng 3. Kết quả thành phần hóa học và cảm quan của nước sơ ri lên men

\begin{tabular}{lccc}
\hline \multirow{2}{*}{ Chỉ tiêu } & \multicolumn{3}{c}{ Độ chín } \\
\cline { 2 - 4 } & $55 \%$ & $90 \%$ & $100 \%$ \\
\hline Tỉ lệ thu hồi (\%) & $19,97^{\mathrm{a}} \pm 3,00$ & $60,38^{\mathrm{a}} \pm 4,29$ & $54,53^{\mathrm{a}} \pm 3,70$ \\
Độ Brix $(\%)$ & $19,4^{\mathrm{a}} \pm 0,8$ & $19,6^{\mathrm{a}} \pm 0,5$ \\
Axít tổng (\%) & $0,65^{\mathrm{a}} \pm 0,03$ & $0,63^{\mathrm{a}} \pm 0,01$ & $0,65^{\mathrm{a}} \pm 0,03$ \\
Vitamin C (mg/100 g) & $648,40^{\mathrm{a}} \pm 120,74$ & $547,64^{\mathrm{a}} \pm 71,81$ & $621,36^{\mathrm{a}} \pm 57,57$ \\
\hline Điểm cảm quan màu sắc & $5,56^{\mathrm{b}}$ & $4,59^{\mathrm{c}}$ & $6,15^{\mathrm{a}}$ \\
Điểm cảm quan mùi & $3,97^{\mathrm{c}}$ & $4,81^{\mathrm{b}}$ & $5,96^{\mathrm{a}}$ \\
Điểm cảm quan vị & $3,93^{\mathrm{c}}$ & $4,37^{\mathrm{b}}$ & $5,45^{\mathrm{a}}$ \\
Cảm quan chung & $3,79^{\mathrm{c}}$ & $4,96^{\mathrm{b}}$ & $6,15^{\mathrm{a}}$ \\
\hline
\end{tabular}

a-c Trong một hàng, các giá trị có cùng ký tự thì khác nhau không có ý nghĩa ở độ tin cậy $95 \%$.

đường ảnh hưởng đến quá trình lên men sản phẩm. Dù được xem là cơ chất thúc đẩy cho quá trình lên men nhưng khi dịch lên men đạt $24 \%$ đường thì quá trình lên men chậm, độ cồn đạt 3,27 độ trong khi $20 \%$ đường là 4,57 độ trong cùng thời gian và nhiệt độ lên men. Theo ArroyoLópez \& ctv. (2009), tốc độ sinh trưởng của nấm men có thể giảm khi tăng nồng độ đường từ 20 đến $30 \%$, kết quả cho thấy nồng độ đường tối ưu là $28,4 \%$. Tuy nhiên, tuỳ thuộc vào điều kiện lên men như tỉ lệ nấm men, loại nấm men, $\mathrm{pH}$, nồng độ đường và loại đường, nhiệt độ lên men có ảnh hưởng đáng kể đến quá trình lên men. Trong nghiên cứu này, tỉ lệ nấm men, nhiệt độ và thời gian lên men cũng được nghiên cứu và trình bày bên dưới.

Qua kết cảm quan vị cho thấy mẫu dịch lên 

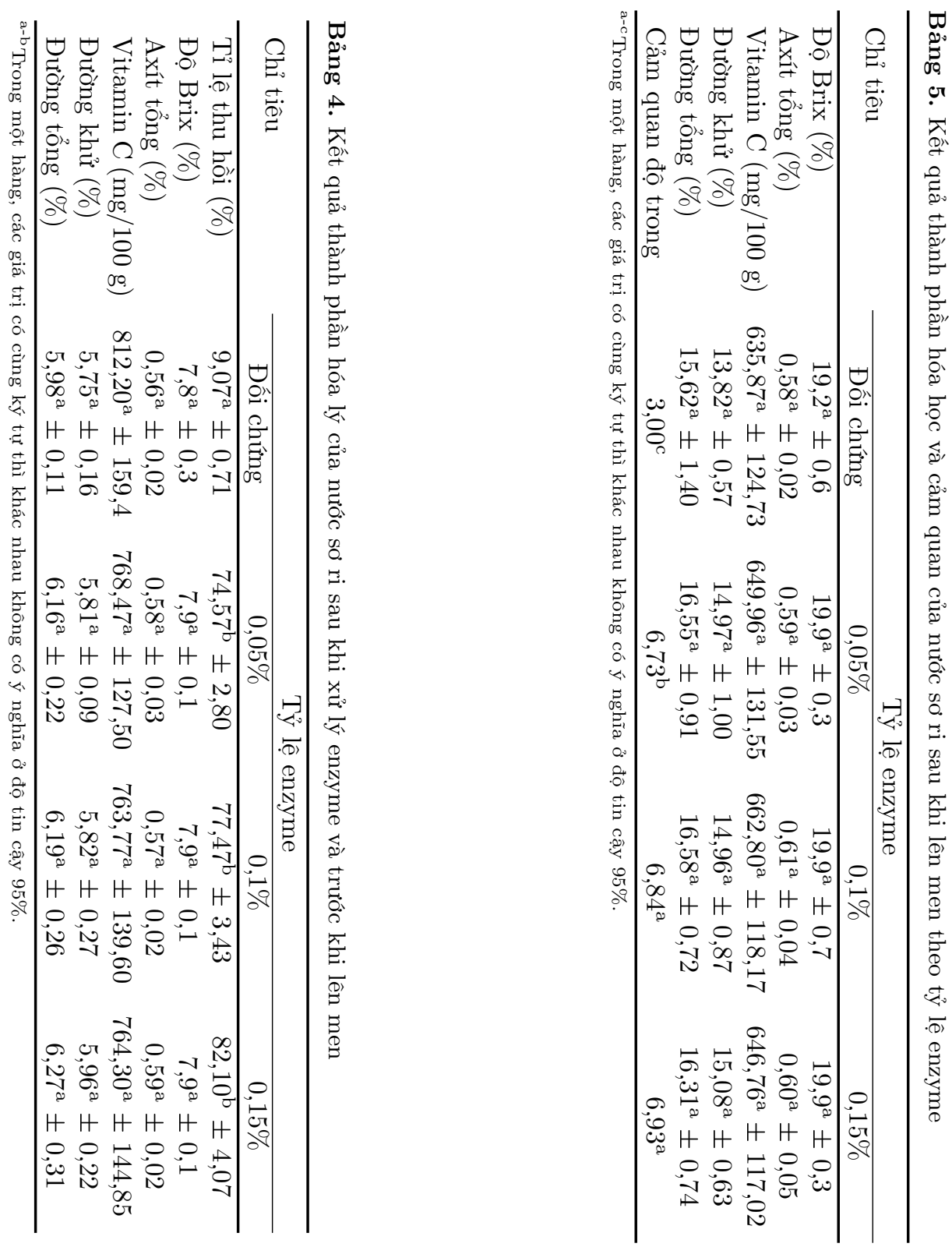

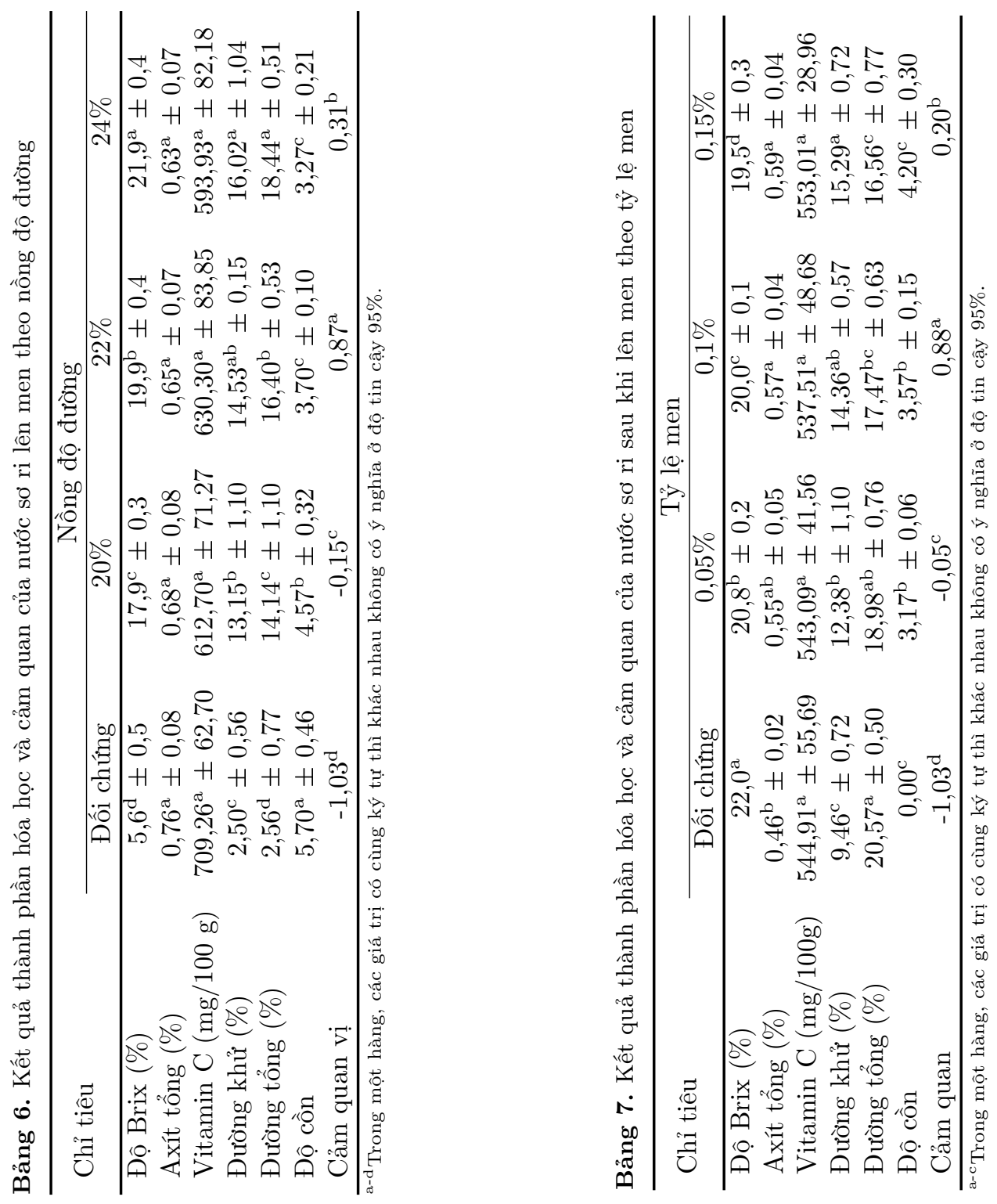
men có tỷ lệ đường $22 \%$ được đánh giá tối ưu nhất, cảm quan viên đánh giá mẫu này có vị chua ngọt hài hòa hơn, đồng thời độ cồn tạo thành cũng vừa phải, có hương thơm nhẹ của nước lên men so với các mẫu còn lại.

Các kết quả trên cũng cho thấy mẫu có hàm lượng đường $22 \%$ sau khi lên men có hàm lượng vitamin $\mathrm{C}$ còn lại cao nhất, các chỉ tiêu hóa học ít biến đổi, độ cồn vừa phải và sản phẩm được đánh giá cảm quan tốt nhất nên được chọn sử dụng làm thông số kỹ thuật trong quy trình lên men.

\section{5. Ảnh hưởng của tỷ lệ men bổ sung đến chất lượng sản phẩm}

Kết quả Bảng 7 cho thấy hàm lượng vitamin C trong sản phẩm không có sự khác biệt ý nghĩa $(P>0,05)$, tỉ lệ nấm men không làm giảm hàm lượng vitamin $\mathrm{C}$. Trong khi đó, độ Brix, đường khử, đường tổng, axít tổng và độ cồn đều có sự khác biệt có ý nghĩa về mặt thống kê (với $P<$ $0,05)$. Khi tăng tỷ lệ nấm men, độ Brix, hàm lượng đường tổng, đường khử sẽ giảm dần, trong khi axít tổng và độ cồn tăng lên.

Kết quả cảm quan cho thấy mẫu bổ sung $0,1 \%$ men được đánh giá tốt do sản phẩm được lên men vừa phải, có vị chua ngọt tương đối hài hòa, lượng cồn tạo ra phù hợp và có hương thơm nhẹ của nước lên men. Mẫu bổ sung 0,15\% men lên men mạnh, tạo mùi rượu quá nồng, sản phẩm có vị đắng, 0,05\% men do có tỷ lệ men ít, quá trình lên men chậm, sau 2 ngày lượng đường còn lại nhiều hơn gây ra sản phẩm có vị ngọt hơi gắt. Đối với mẫu đối chứng (mẫu không bồ sung nấm men) do nhiệt độ lên men thấp ở $15-20^{\circ} \mathrm{C}$ hầu như không xảy ra quá trình lên men.

Như vậy, qua các chỉ tiêu hóa học và cảm quan tỷ lệ men bổ sung là $0,1 \%$ được chọn là thích hợp nhất để lên men sản phẩm.

\section{6. Ảnh hưởng của nhiệt độ và thời gian lên men đến chất lượng sản phẩm}

Sau khi xác định được nồng độ đường và tỉ lệ nấm men sử dụng, nhiệt độ và thời gian là một trong những điều kiện quan trọng ảnh hưởng đến chất lượng sản phẩm. Kết quả xác định ảnh hưởng của nhiệt độ và thời gian đến chất lượng hoá học và cảm quan được trình bày qua Bảng 8 .

Kết quả ở Bảng 8 cho thấy độ Brix và vitamin C giữa các mẫu có sự khác biệt t có ý nghĩa với $P$ 
$<0,05$. Quá trình lên men vẫn tiếp tục diễn ra, làm cho độ Brix giảm dần theo thời gian. Theo Peddie (1990), nhiệt độ cao giúp quá trình lên men xảy ra nhanh hơn, các màng tế bào trở nên lỏng lẻo hơn, tạo điều kiện cho các enzyme hoạt động mạnh. Do đó, với cùng một thời gian nhưng ở hai mức nhiệt độ $15^{0} \mathrm{C}$ và $30^{\circ} \mathrm{C}$, độ Brix ở $15^{0} \mathrm{C}$ $(23,67 \%)$ cao hơn độ Brix ở $30^{\circ} \mathrm{C}(20,67 \%)$. Hàm lượng vitamin $\mathrm{C}$ ở cùng mức nhiệt độ giảm dần theo thời gian. Các mẫu lên men ở nhiệt độ $15^{0} \mathrm{C}$ có hàm lượng vitamin $\mathrm{C}$ giảm thấp hơn so với các mẫu lên men ở $30^{\circ} \mathrm{C}$.

Kết quả cảm quan và kết quả xử lý thống kê cho thấy giữa các mẫu sự khác có ý nghĩa về mặt thống kê $(P<0,05)$. Trong đó, mẫu lên men ở $15^{0} \mathrm{C}$ trong 2 ngày được đánh giá cao điểm hơn (0,96 điểm) so với các mẫu còn lại, với đặc tính cảm quan được nhận định bởi các cảm quan viên là mùi thơm hài hòa giữa mùi sơ ri và mùi lên men, lượng gas vừa phải, màu vàng đặc trưng của sơ ri. Mẫu lên men ở $30^{\circ} \mathrm{C}$ trong 3 ngày được đánh giá thấp hơn các mẫu còn lại, với màu vàng nhạt, vị đắng chát, khó uống.

Từ kết quả hóa học và xử lý thống kê về cảm quan, điều kiện lên men ở nhiệt độ $15^{0} \mathrm{C}$ trong 2 ngày được chọn sử dụng trong quy trình chế biến nước sơ ri lên men, do ở nhiệt độ và thời gian này, quá trình lên men dễ kiểm soát hơn, mùi vị nước sơ ri lên men.

\section{7. Ảnh hưởng của chế độ thanh trùng đến chất lượng sản phẩm}

Để sản phẩm nước quả lên men có thể bảo quản lâu, xử lý nhiệt là một trong những công đoạn quan trọng. Nhiệt độ và thời gian cần được xác định sao chất lượng sản phẩm bị thay đổi là ít nhất sau quá trình thanh trùng (Bảng 9) và trong suốt thời gian bảo quản (Bảng 10 và 11 ).

Hàm lượng vitamin $\mathrm{C}$ của các cặp nghiệm thức $\mathrm{NT} 1$ và $\mathrm{NT} 4, \mathrm{NT} 2$ và $\mathrm{NT} 5, \mathrm{NT} 3$ và $\mathrm{NT} 6$ có sự khác biệt không có ý nghĩa về mặt thống kê với $P<0,05$, chứng tỏ trong cùng một thời gian xử lý ở hai mức nhiệt độ $80^{\circ} \mathrm{C}$ và $85^{\circ} \mathrm{C}$ thì không ảnh hưởng hàm lượng vitamin $\mathrm{C}$. Tuy nhiên, hàm lượng vitamin $\mathrm{C}$ giảm khi thời gian thanh trùng tăng ( 5 phút, 10 phút và 15 phút) và thanh trùng ở nhiệt độ cao trong thời gian ngắn sẽ giữ được nhiều vitamin $\mathrm{C}$ hơn.

Điểm cảm quan cho thấy sự khác biệt giữa các mẫu có ý nghĩa về mặt thống kê với $P<0,05$. Theo nhận xét người đánh giá cảm quan, màu sắc

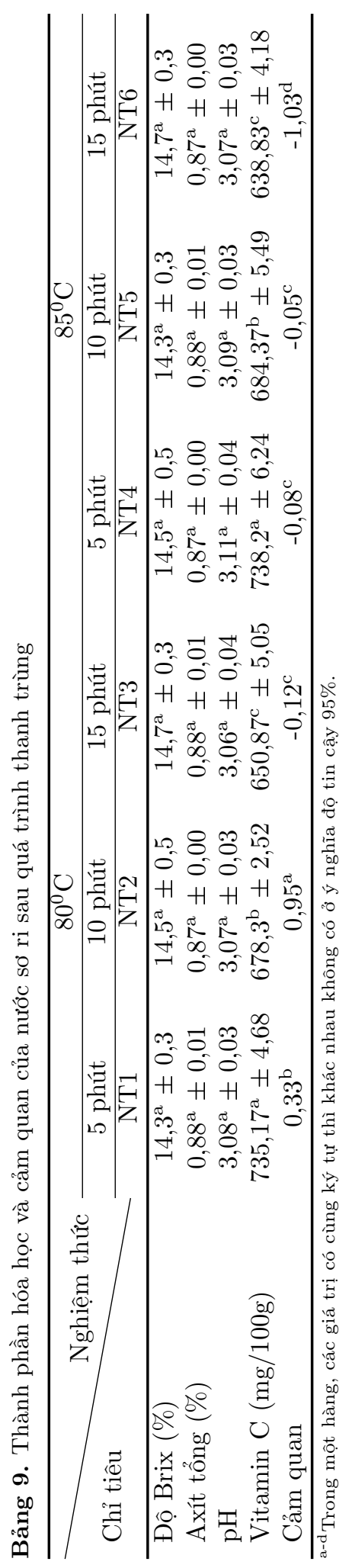


Bảng 10. Thành phần hóa học của sản phẩm sau bảo quản

\begin{tabular}{lccc}
\hline Thành phần & Sau 1 ngày & Sau 3 tháng & Sau 6 tháng \\
\hline Độ Brix (\%) & 20,0 & 20,0 & 20,0 \\
Độ axít (\%) & 0,57 & 0,58 & 0,56 \\
Vitamin C (mg/100g) & 537,51 & 500,23 & 450,28 \\
Đường khử (\%) & 14,36 & 14,34 & 14,37 \\
Đường tồng (\%) & 17,47 & 17,44 & 17,46 \\
Độ cồn & 3,57 & 3,58 & 3,38 \\
\hline
\end{tabular}

Bảng 11. Kết quả kiểm tra vi sinh sản phẩm nước sơ ri lên men sau 6 tháng bảo quản

\begin{tabular}{|c|c|c|c|c|}
\hline \multirow{2}{*}{ Tên chỉ tiêu } & \multirow{2}{*}{$\begin{array}{c}\text { Giới hạn tối đa } \\
\text { (QCVN 6-3:2010/BYT) }\end{array}$} & \multicolumn{2}{|c|}{ Kết quả } & \multirow{2}{*}{ Phương pháp thử } \\
\hline & & 3 tháng & 6 tháng & \\
\hline $\begin{array}{l}\text { E. coli, } \\
\mathrm{CFU} / \mathrm{mL} \text { sản phẩm }\end{array}$ & $\begin{array}{l}\text { Không } \\
\text { được có }\end{array}$ & $<01$ & $<01$ & $\begin{array}{l}\text { TCVN 6846:2007 } \\
\text { (ISO 7251:2005) }\end{array}$ \\
\hline $\begin{array}{l}\text { Coliform, } \\
\text { CFU/mL sản phẩm }\end{array}$ & $\begin{array}{l}\text { Không } \\
\text { được có }\end{array}$ & $<01$ & $<01$ & $\begin{array}{l}\text { TCVN 6848:2007 } \\
\text { (ISO 4832:2006) }\end{array}$ \\
\hline $\begin{array}{l}\text { Staphylococcus aureus, } \\
\mathrm{CFU} / \mathrm{mL} \text { sản phẩm }\end{array}$ & $\begin{array}{l}\text { Không } \\
\text { được có }\end{array}$ & $\begin{array}{l}\text { Không } \\
\text { phát hiện }\end{array}$ & $\begin{array}{l}\text { Không } \\
\text { phát hiện }\end{array}$ & $\begin{array}{l}\text { TCVN 4830-1:2005 } \\
\text { (ISO 6888-1:2003) }\end{array}$ \\
\hline $\begin{array}{l}\text { Clostridium perfringens, } \\
\mathrm{CFU} / \mathrm{mL} \text { sản phẩm }\end{array}$ & $\begin{array}{l}\text { Không } \\
\text { được có }\end{array}$ & $\begin{array}{l}\text { Không } \\
\text { phát hiện }\end{array}$ & $\begin{array}{l}\text { Không } \\
\text { phát hiện }\end{array}$ & $\begin{array}{l}\text { TCVN 4991:2005 } \\
\text { (ISO 7937:2004 }\end{array}$ \\
\hline $\begin{array}{l}\text { Tổng số nấm men và nấm mốc, } \\
\text { CFU/mL sản phẩm }\end{array}$ & 100 & $<01$ & $<01$ & $\begin{array}{l}\text { TCVN 8275-1:2009 } \\
\text { (ISO 21527-1:2008) }\end{array}$ \\
\hline
\end{tabular}

${ }^{1}$ Theo phương pháp thử, kết quả được biểu thị nhỏ hơn $10 \mathrm{CFU} / \mathrm{g}$ hoặc nhỏ hơn $1 \mathrm{CFU} / \mathrm{g}$ khi không có khuẩn lạc mọc trên đĩa.

của mẫu NT2 có màu vàng đặc trưng của thịt quả sơ ri, mùi vị hài hòa, vừa có mùi thơm của sơ ri tươi và mùi men. Hai mẫu $\mathrm{NT} 1\left(80^{\circ} \mathrm{C} / 5\right.$ phút) và $\mathrm{NT} 2\left(80^{\circ} \mathrm{C} / 10\right.$ phút) được đánh giá cao hơn các mẫu khác, khi thanh trùng ở thời gian ngắn hơn sẽ giữ được mùi hương cho sản phẩm. Xét về hàm lượng vitamin $\mathrm{C}$ còn lại giữa 2 mẫu, mẫu NT1 cao hơn mẫu NT2 khoảng 56,867 mg/100 g. Tuy nhiên, xét về mặt cảm quan, mẫu NT2 và mẫu NT1 sự sai khác rất có ý nghĩa ở độ tin cây $95 \%$. Do đó, chế độ thanh trùng ở $80^{\circ} \mathrm{C}$ trong 10 phút được chọn sử dụng trong quy trình chế biến nước sơ ri lên men do đảm bảo được lượng vitamin $\mathrm{C}$ còn lại tương đối cao, cảm quan phù hợp thị hiếu của người tiêu dùng và ức chế được quá trình lên men, hạn chế vi sinh vật trong sản phẩm.

\subsection{Chất lượng sản phẩm sau 6 tháng bảo quản}

Sau 6 tháng bảo quản các chỉ tiêu độ Brix, độ axít, đường tổng, đường khử, độ cồn của sản phẩm không có sự thay đổi nhiều. Hàm lượng vitamin C sau 6 tháng giảm 87,23 mg/100 g, tương đối thấp so với sau khi thanh trùng 1 ngày nhưng vẫn còn cao so với các sản phẩm khác.

\section{Kết Luận và Đề Nghị}

\subsection{Kết luận}

Kết quả nghiên cứu cho thấy trong 3 giống sơ ri ngọt, sơ ri chua và sơ ri Brazil thì giống sơ ri chua truyền thống có độ chín $100 \%$ thích hợp nhất để làm nguồn nguyên liệu chế biến nước sơ ri lên men. Xử lý enzyme Pectinex ultra SP-L với tỷ lệ $0,15 \%$ là thích hợp để làm trong dịch quả. Nồng độ đường thích hợp cho dịch lên men là $22^{0} \mathrm{Bx}, 0,1 \%$ men (Saf- instant, Pháp). Quá trình lên men ở nhiệt độ $15^{0} \mathrm{C}$ trong 2 ngày giúp sản phẩm lên men tốt, đạt cảm quan tốt nhất. Nhiệt độ thanh trùng $80^{\circ} \mathrm{C}$ trong 10 phút ức chế được các vi sinh vật gây hư hỏng, hạn chế quá trình lên men và vẫn đảm bảo hương vị cho sản phẩm nước sơ ri lên men. Sau 6 tháng bảo quản, sản phẩm vẫn đảm bảo được màu sắc, mùi vị, và các chỉ tiêu vi sinh khảo sát. Quy trình chế biến nước sơ ri lên men được xác định như Hình 3. 


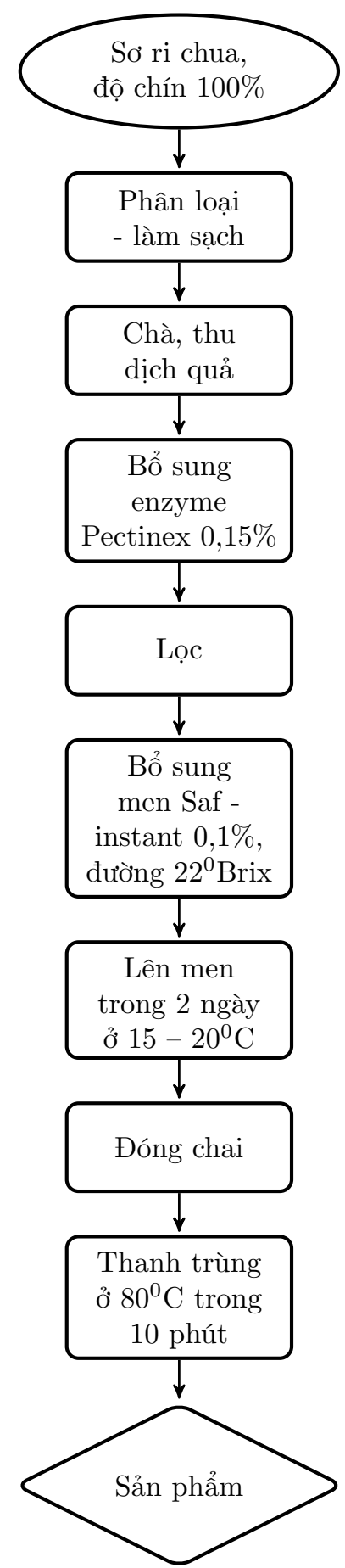

Hình 3. Sơ đồ quy trình chế biến nước sơ ri lên men.

\section{2. Đề nghị}

Để hoàn thiện quy trình, cần phân tích đầy đủ các chỉ tiêu đã quy định trong tiêu chuẩn.

Ngoài ra, đề nghị khảo sát các phương pháp lọc để loại bỏ xác men sau khi lên men giúp tăng giá trị cảm quan cho sản phẩm.

\section{Tài Liệu Tham Khảo (References)}

Arroyo-López, F. N., Orlić, S., Querol, A., \& Barrio, E. (2009). Effects of temperature, $\mathrm{pH}$ and sugar concentration on the growth parameters of Saccharomyces cerevisiae, S. kudriavzevii and their interspecific hybrid. International Journal of Food Microbiology 131(2-3), 120-127.

Delva, L., \& Schneider, R. G. (2013). Acelora (Malpighia emarginata DC): Production, Postharvest handling, Nutrition, and Biological Activity. Food Reviews International 29(2), 107-126.

Ha, T. D. (2000). Methods for sensory analysis of food. Ha Noi, Vietnam: Science and Technics Publishing House.

Horemans N., Foyer, C.H., \& Asard, H. (2000). Transport and action of ascorbate at the plant plasma membrane. Trends in plants Science 5(6), 263-267.

Johnson, P. D. (2003). Acelora (Malpighia glabra L., M. punicifolia L., M. emarginated D.C): Agriculture, production and nutrition. World Review of Nutrition and Dietetics 91, 67-75.

Lam, P. K. (2009). Vitamin C (Unpublished bachelor's thesis). University of Technology, Ho Chi Minh City, Vietnam.

Lawless, H. T., \& Heymann, H. (2010). Sensory evaluation of food: Principles and practices. New York, USA: Springer

Nguyen, M. V. (2004). Biochemical practice. Ha Noi, Vietnam: Science and Technics Publishing House.

Peddie, H. A. B. (1990). Ester formation in brewery fermentations. Journal of the Institute Brewing 96(5), 327-331.

Rocha, I. F. O., \& Bolini, H. M. A. (2015). Passion fruit juice with different sweeteners: Sensory profile by descriptive analysis and acceptance. Food Science and Nutrition 3(2), 129-139.

Sharma, H. P., Patel, H., \& Sugandha. (2017). Enzymatic added extraction and clarification of fruit juices - A review. Critical Reviews in Food Science and Nutrition 57(6), 1215-1227.

QCVN (Technical Regulations of Vietnam). (2010). QCVN 6-3:2010/BYT: National technical regulations for alcoholic beverages. Ha Noi, Vietnam: Ministry of Health.

Stone, H., \& Sidel, J. (2004). Sensory evaluation practices ( $3^{\text {rd }}$ ed.). California, USA: Academic Press. 
TCVN (Vietnamese National Standards). (2009). TCVN 8008:2009: Distilled alcohol-alcoholic content determination. Ha Noi, Vietnam: Ministry of Science and Technology.

Tran, L. T. B., Ton, N. M. N., \& Dinh, T. N. T. (2004). Biochemical food experiment. Ho Chi Minh City, Vietnam: VNUHCM Publishing House.
Vendramini, A., \& Trugo, L. (2000). Chemical composition of acelora fruit (Malpighia punicifolia L.) at three stages of maturity. Food chemistry 71(2), 195-198. 